\title{
Paula Stradina Medicīnas vēstures muzejs Latvijas PSR Zinātṇu akadēmijas sastāvā (1946-1952)
}

Referāts nolasīts 23. Starptautiskajā Baltijas Zinātnuu vēstures konferencē (K. Ē. Arona pieminas sēdē) 2008. gada 9. oktobrī

\section{Jānis Stradinš̌, Dzintra Cēbere}

Paula Stradiṇa Medicinnas vēstures muzejs tika izveidots un faktiski sāka darboties 1945. gada vasarā Valsts klīniskās slimnīcas plašā barakā (19 istabās un divās lielās zālēs), taču tā juridiskais statuss līdz 1957. gadam palika nenoteikts. Tas bija atkarīgs no dibinātāja profesora Paula Stradiņa (1896-1958) ieņemamās pozīcijas kādā no daudzajām tolaik viṇa vadītajām iestādēm - slimnīcā, LVU Medicīnas fakultātē, un kopš 1946. gada Latvijas PSR ZA, kur no 1946. lìdz 1951. gadam P. Stradiņš bija Bioloǵijas un eksperimentālās medicinas institūta direktors [I].

Ierosinājums vēstures muzeju pievienot jaundibinātajai Zinātņu akadēmijai tika akceptēts 1946. g. 25. jūlijā prezidenta P. Lejiṇa vadītajā Latvijas PSR Zinātṇu akadēmijas prezidija sēdē. Tã paša gada 29. augustā ar P. Lejiṇa un J. Peives parakstu Latvijas PSR Ministru Padomei tika nosūtīts lūgums sadalìt Bioloǵijas un eksperimentālās medicīnas institūtu divos atsevišķos institūtos - Eksperimentālās medicīnas un Biologijas institūtā un dibināt Medicīnas vēstures muzeju kā ZA atsevišķ struktūrvienību [2]. No Zinātṇu akadēmijas (P. Stradiṇa) puses tika sagatavots arī attiecìgs Ministru Padomes lēmumprojekts, datēts ar 1946. gada .. augustu [3], taču Latvijas PSR Ministru Padome to neakceptēja un tas nestājās spēkā. Iemesls varētu būt tas, ka lēmumprojekts paredzēja gan atsevišķরa Biologíijas institūta veidošanu Latvijas PSR sastāvā (ko acīmredzot nevēlējās bioloǵijas zinātṇu sarežğìtā stāvokḷa dẹl toreizèjā PSRS un Latvijas PSR vadības attieksmes dēl pret prof. P. Galenieku) [4], gan arī P. Sniḳera mājas-muzeja kā Medicīnas vēstures muzeja otras sastāvdaļas izveidošanu Mežaparkā. Acīmredzot šo divu tolaik neatrisināmo problēmu dēl arī P. Stradiṇa Medicīnas vēstures muzeja kā pat- 
stāvīgas institūcijas projekts netika akceptēts. Vēlamies labot neprecizitāti rakstā "Acta Medico-Historica Rigensia", VIII sēj. [5], kurā minēts, ka MP lēmumu ir atbalstijusi.

Muzejs formāli nonāca P. Stradiṇa vadītajā Biologiijas un eksperimentālās medicīnas institūta sastāvā kā tā neoficiāla struktūrvienība, taču vienlaikus atradās Republikas Klīniskās slimnīcas telpās, par kurām ZA vadība (īpaši Lietu pārvaldnieks J. Vecvagars) nevēlējās uzṇemties atbildību, ìpaši pēc tam, kad 1947. gadā, V. I. L̦eṇina nāves dienā, tur bija izcēlies ugunsgrēks.

Pirmais Medicīnas vēstures muzeja pārzinis bija Jānis Jākobsons (1879-1950), institūta direktora vietnieks administratīvajā darbā, pēc tam - Lāčplēša ordeṇa kavalieris Aleksandrs Teters (1892-1969). Muzejā kā bibliotekārs darbojās Alfrēds Goba, vairāki mākslinieki (kā štata darbinieki - L. Kokle, G. Cîlìis, R. Tillbergs u. c.). Daudzi mākslinieki (prof. J. R. Tillbergs, V. Caune, P. Glaudāns, I. Stradiṇa u. c.) darbojās uz brīva līguma pamata. Muzeja baraku pārraudzīja sanitārs Mihails Kuṇecs (1925-2008), vēlāk ārsts Ainažos, kur miris un apbedīts. Miša iekārtojās barakā uz dzīvi mazā istabiṇā pie bibliotēkas. Telpu stāvoklis kḷuva arvien bēdīgāks, barakai bija bojāts jumts.

Pēc P. Stradiña aiziešanas no institūta direktora amata jaunais direktors akadēmiķis A. Šmits pret muzeju bija noskan,ots drīzāk noraidoši, kā izriet no E. Cielēna atmiṇām [6].

1952. gada 5. februārī pēc akadēmiķa A. Šmita ziņojuma pieṇemtajā Latvijas PSR ZA Prezidija lēmumā sacìts, ka "1. Latvijas PSR Zinātṇu akadēmijai brīvu telpu trūkuma dēḷ Medicīnas vēstures muzeja organizēšanai nav iespējams izlietot un pieņemt Latvijas PSR ZA istenā locekḷa profesora doktora P. Stradiņa šim nolūkam piedāvātas eksponātu kolekcijas, kas pieder viṇam personiski; 2. Zinātņu akadēmija uzskata par lietderīgu un lūdz profesoru Paulu Stradin̨u nodot savas vērtīgās eksponātu kolekcijas Latvijas PSR Veselības aizsardzības ministrijai, lai pie pēdējās organizētu Veselïbas aizsardzības vēstures muzeju" [5, 58. lpp.].

Ar šo aktu faktiski beidzās Medicīnas vēstures muzeja pastāvēšana ZA sastāvā, un tālākais tā liktenis saistās ar Rịgas Medicīnas institūtu un Veselības aizsardzības ministriju, kuras pakḷautībā beidzot 1957. gada septembrī tika oficiāli organizēts muzejs, kas vēra durvis plašam apmeklētāju lokam 1961. gadā.

\section{Vēres}

1. Stradin̦š J., Arons K.Ē., Vìksna A. Tāds bija mūsu laiks... Rīga: Sprīdītis, 1996. 491 lpp.

2. LZA Arhīvs, 1. f., 1. apr., 10. 1., 114.-115. lp.

3. LZA Arhivs, 1. f., 1. apr., 10. 1., 116. lp.

4. Stradinš̌ J. Stalina režīma attieksme pret Latvijas zinātniekiem un akadēmiskajām aprindām.//Latvijas Vēsturnieku komisijas Raksti. 19. sēj. Okupētā Latvija, 


\section{J. Stradinš̌, D. Cēbere}

1940-1990. Rīga: LVI apgāds, 2007, 408.-448. lpp. (kopsavilkums angḷu valodā: 446.-448. lpp.).

5. Stradiņš J. Paula Stradina Medicīnas vēstures muzeja tapšana un izveidošanās.// Acta Medico-Historica Rigensia. Vol. 8 (27). Rìga: 2007, 50. lpp.; Stradin̦š J. Latvijas Zinātñu akadēmija: izcelsme, vēsture, pārvērtības. Rīga: Zinātne, 1998, 143. lpp.

6. Cielēns E. Atmiṇas par profesoru P. Stradiṇu un prof. A. Šmitu Zinātṇu akadēmijā (1986).//Acta Medico-Historica Rigensia. Vol. 8 (27). Rìga: 2007, 352.-356. lpp.

\section{Pielikums № 1}

LZA Arhīvs, 1. f., 1. apr., 4. 1., 34., 36., 37. lpp.

Latvijas PSR Zinātṇu Akadēmijas

Prezidija sēdes

Protokols Nr. 9.

Rīgā, 1946. g. 25. jūlijā, plkst. 18.10

Piedalās: ZA Viceprezidents M. Kadeks, Akadēmiḳis-sekretārs J. Peive;

Prezidija locekḷi: A. Kirchenšteins, P. Valeskalns un ZA Lietu pārvaldnieks J. Vecvagars. Pieaicināti: îstenais loceklis P. Stradiņš, Ķīmijas institūta direktors Ieviņš, Serumstacijas direktors Vīksne, Vēstures un materiālās kultūras institūta direktora vietn. Stepermanis.

Sēdi vada ZA Viceprezidents Prof. Dr. M. Kadeks

Protokolē ZA Prezidenta referents J. Magone.

Dienas kārtỉba:

4. İstenā locekḷa P. Stradiṇa ierosinājums par Biologiijas un eksperimentālās medicinas institūta pārorganizēšanu /34. lpp./

Apspriež: /36. lpp./

4. Pie ceturtā dienas kārtības punkta par Biologijas un eksperimentālās medicīnas institūta direktora P. Stradiṇa 1946. g. 20. jūlija rakstu, t. i., ierosinājumu par institūta pārorganizēšanu/raksts pievienots protokolam/ziņo prof. Dr. P. Stradiņšs.

I. Sakarā ar Bioloǵijas un eksperimentālās medicīnas institūta sekciju un štatu samazināšanu Valsts štatu komisijā minētais institūts agrāk paredzētajā veidā un apmēros darboties nevar. Nevarēs pastāvēt arī apvien ots Biologíijas un eksperimentālās medicīnas institūts, jo nav tik vispusīga zinātnieka, kas sevī apvieno zināšanas divu tādu institūtu sekmīgai vadī̌sanai un attīstǐšanai. 
Tamdēḷ lūdz - samazināt viṇa vadīto institūtu, nosaucot to par Eksperimentālās medicīnas institūtu, un nodalìt Biologiijas dalıu, sadalot pēdējo Mikrobioloǵijas un Eksperimentālās medicīnas institūtiem.

[Pie I] Nolemj:

I. Lūgt Ministru Padomi:

a) Dibināt Biolog̣ijas institūtu, nosaucot tagadējo Bioloǵijas un eksperimentālās medicīnas institūtu par "Eksperimentālās medicinnas" institūtu.

b) Dibināt Medicīnas muzeju kā atsevišķu ZA vienību ar divām novietnēm.

Lūgt īsteno locekli P. Stradinu izstrādāt Ministru Padomes lēmumu projektus ar attiecīgiem paskaidrojumiem, kā arī vajadzīgo štatu projektus

II. [Apspriež] Tālāk prof. Dr. P. Stradiṇš lūdz Prezidija norādijjumus darbnīcas iekārtošanas un organizēšanas jautājumos. Kārtīga darbnīca institūtam pilnīgi nepieciešama, jo nekavējoties jāizgatavo institūta vajadzībām dažādi aparāti un piederumi, bez kādiem institūts nevar iztikt un kuru saṇemšana no centra nav tik ātri sagaidāma. Līdztekus darbnīcā jālabo esošā aparatūra, kamdēḷ tur 5 darba vienïbas nepieciešamas.

[Pie II] Nolemj:

II. Institūta darbnīcu izveidot uz saimnieciska aprēḳina (pašizmaksas) pamata.

Medicīnas muzeju lietās Prof. Dr. P. Stradiņš ziņo, ka:

I. Pastāv viṇa iekārtots Medicīnas vēstures muzejs, kura eksponāti aizṇem 25 istabas. Tas savākts un iekārtots ar profesora Dr. P. Stradiṇa personigajiem līdzekḷiem, bet viņš /36./37. lpp./ vēlētos to nodot Akadēmijai ar noteikumu, ka Akadēmija viṇu atstāj par šì muzeja bezalgas kuratoru, t. i., direktoru.

II. Prof. Dr. P. Sniķers atstājis trīsstāvu māju ar gleznu u. c. kolekcijām. Nelaiķis vēlējies, lai dibinātu muzeju viņa vārdā. Nams ar mantām saglabāts un remontēts un pagaidām atrodas LVU Medicīnas fakultātes pārzin̄ā. Arī še vajadzīgs kurators, un būtu lietderīgi minēto namu lìdz ar mantām nodot $\mathrm{Z}$ Akadēmijai. Muzejus varētu apvienot, dažas istabas atstāt prof. P. Sniḳera piemiņai, citas medicīnas darbinieku rīcībā.

Uz Akadēmiķa-sekretāra J. Peives jautājumu, cik darbinieku tagad apkalpo Medicīnas muzeju, un uz Prezidija locekḷa A. Kirchenšteina jautājumu, kas strādā Eksperimentālās medicīnas institūtiem, atbild prof. P. Stradiņšs, ka muzejā strādā viņš viens pats un Biologijas nodal̦ā prof. Galenieks, Redliha un Pučko. 


\section{J. Stradinš̌, D. Cēbere}

Augšā minēto prof. Dr. Stradina ierosinājumu apspriešanā piedalās visi Prezidija locekli, pie kam izsaka domas, ka:

I. Biolog̣ijas un eksperimentālās medicīnas institūta Biolog̣ijas nodaḷu likvidēt nevar;

II. Nepieciešamos darbiniekus pagaidām var pieaicināt no citiem institūtiem;

III. Darbnīcas iespējams organizēt uz saimnieciskā aprēḳina (pašizmaksas) pamata;

IV. Pēc apstiprināto štata vienību aizpildī̌sanas varēs lemt par jaunu štata vienïbu pieprasišsanu.

V. Institūta Bioloǵijas daļai ar prof. Galenieku priekšgalā rìkoties pēc iespējas patstāvīgi, seviški saimnieciskos jautājumos, līdz turpmākam sazinoties ar pagaidām apvienotā Biolog̣ijas un eksperimentālās medicīnas institūta direktoru prof. P. Stradinu.

$=37$. lpp.

Sēdi slēdz plkst. 20.00

ZA Viceprezidents

Prof. Dr. M. Kadeks = paraksts

ZA Prezidenta referents

J. Magone $=$ paraksts

\section{Pielikums № 2}

LZA Arhīvs, 1. f., 1. apr., 10. 1., 117.-119. lpp.

[П. Я. Страдыньш 20 июля 1946.]

Президенту Академии Наук Латвийской ССР

При составлении штатного расписания Института биологии и экспериментальной медицины в составе последнего, кроме административного аппарата были намечены 8 секторов, музей и архив истории медицины и ремонтная мастерская для инструментов и аппаратов. Штатные единицы были представлены в минимальном количестве, так, например для Музея истории медицины, занимающего 25 комнат и являющегося в данную минуту самым крупным, уже развернутым музеем этого типа во всем Советском Союзе, были намечены только 9 сотрудников; для ремонтных мастерских, в которых можно изготовить основные приборы для всего института, были намечены 5 сотрудников, для отдельных секторов по 6-9 сотрудников, итого 93 штатные единицы. Между тем утверждены 57 штатные единицы, в том числе 4 заведующих секторами и лабораториями, 10 старших научных сотрудников и 8 младших научных сотрудников. С таким количеством штатных единиц успешная планировка работы института невозможна. Поэтому прошу 
либо увеличить количество штатных единиц до 93/в крайнем случае до 85, если каждый сектор сократить на одну штатную единицу/либо разрешить перепланировать структуру Института. Предоставленные штаты достаточны только для работы 4 секторов, в крайнем случае пяти/если считать, что директор института одновременно будет руководить одним из секторов/. В случае невозможности увеличения штатов, прошу разрешить следующую перепланировку института:

1. Сектор биологии должен быть отделен от института и последний впредь должен носить название Института экспериментальной медицины. Это тем более необходимо, что само обьединение столь широких дисциплин как вся биология и экспериментальная медицина, при имеющихся минимальных штатах практически невозможна и кроме того, также и нелогична, если в составе Академии гораздо более узкие дисциплины, как микробиология и вопросы питания выделены в отдельные институты с бо́льшим количеством сотрудников/Институт микробилогии, директор А. Кирхенштейн; Институт питания, директор А. Шмидт. - aвm./. В равной мере почти невозможно найти такого директора института, который мог бы объединить в своем лице достаточно авторитетное руководство по всем разделам экспериментальной медицины и кроме того был бы хорошо осведомленным научным работником по всем биологическим дисциплинам. 117/118 c.

2. Сектор туберкулеза, хотя и должен был бы быть одной из весьма важных составных частей института, может быть отделен и объединен с разделом туберкулеза Института микробиологии, тем более что тематика обоих секторов в значительной степени обобщена.

3. Сектор фармакологии и фармакогнозии может быть упразднен как самостоятельная единица; вопросы фармакодинамики могут быть изучены в составе сектора физиологии, раздел же фармакогнозии может быть включен в состав сектора изучения естественных лечебных факторов в качестве небольшой подгруппы.

4. Вопрос о включении Музея истории медицины может быть разрешен только при условии увеличения штатного расписания на 9 единиц. Разрешенные три штатные единицы/заведующий музеем, чертежник и фотограф/ будут полностью использованы для музея сектора онкологии, имеющего уже сейчас выше 500 экспонатов/в том числе свыше 150 муляжей/и расположенного в 5 комнатах. Кроме музея онкологии в составе института намечен еще музей сектора морфологии, так что в будущем году для успешной работы всех трех музеев будет необходимо иметь по крайней мере 16-18 сотрудников/в том числе 10-12 для музея истории медицины/. Что касается последнего, то могу подчеркнуть, что развертываемый в Ленинграде Музей истории медицины Красной Армии имеет штат свыше 200 сотррудников, а любой дом санитарного просвещения с музеем, имеющий более узкую тематику, по стандартным расписаниям имеет 18 штатных единиц. 


\section{J. Stradinš̌, D. Cēbere}

5. Чрезвычайно важным вопросом является организация ремонтных мастерских, в которых не только должна ремонтироваться аппаратура, но где в основном будут изготовлены целый ряд аппаратов и приборов для нужд института. Институт должен начать свою работу почти без всякой аппаратуры; по наведеным справкам в центральных учреждениях Москвы и Ленинграда едва ли можно будет немедленно приобрести всю необходимую аппаратуру; последняя будет отпущена частично и то только в более поздние сроки. При наличии достаточно квалифицированных мастеров значительная часть аппаратуры могла бы быть приготовлена на месте.

6. Ставки для административно-хозяйственного и в особенности для научно-технического персонала нужно считать совершенно неприемлемым для условной работы в Риге, так как большинство учреждений платят гораздо больше, и поэтому многие сотрудники, узнав о низких ставках, взяли свои заявлелния о приеме на работу обратно /118/119 c./

7. Так как Институт Экспериментальной медицины не имеет своей базы, то необходимо либо срочно добиться отвода помещений под институт, либо разрешить довольно крупные средства /от 80 т. руб. до 100 тысяч рублей/ для ремонта некоторых зданий, предоставленных институту Государственной клинической больницей/корпус музея истории медицины, аудитории и музей онкологии, виварий, //следующий текст вычеркнут карандашом специально выстроенный по планам физиологического института в Колтушах//, два корпуса под сектора онкологии и биофизики и биохимии/.

Чтобы скорей развернуть работу института, указанные изменения структуры института, прошу провести в самые ближайшие сроки, т. к. в ноябре либо в декабре институт предполагает провести свою первую научную сессию.

Рига, "20" июля 1946 г.

/проф. Др. мед. П. Страдиньш/

Проф. П. Страдыньш = подпись

Директор института биологии и экспер.

медицины

LZA Arhīvs, 1. f., 1. apr., 10.1., 117.-119. lp.

\section{Pielikums № 3}

LZA Arhīvs, 1. f., 1. apr., 10. 1., 114.-115. lp.

$114 \mathrm{c}$.

29 августа 1946 г.

В Совет Министров Латвийской ССР

Пояснительная записка.

В соответствии с утвержденной структурой Академии Наук Латвийской ССР в состав Академии входит научно-исследовательский институт Био- 
логии и экспериментальной медицины. Перед этим институтом поставлены большие и серьезные задачи, так как в нем объединены две широкие дисциплины: биология и экспериментальная медицина. Для успешного развертывания работы института требуется соответствующее количество работников. При составлении штатного расписания института было предусмотрено минимальное количество штатных единиц - 93. Государственной Штатной Комиссией однако утвержден лишь штат в количестве 57 единиц. Так как утвержденные штаты являются недостаточными и это обстоятельство не позволит институту успешно выполнить поставленные перед ним задачи, Президиум Академии Наук на своем заседании от 25-го июля 1946 г./ прот. №9/ решил, что необходимо переорганизировать структуру института, а именно:

Надо отделить от института Сектор биологии и на базе последнего учредить новый научно-исследовательский институт Биологии в качестве отдельной структурной единицы Академии Наук; теперешний Институт Биологии и экспериментальной медицины впредь должен носить название Института Экспериментальной медицины. При имеющихся минимальных штатах невозможно объединение двух столь широких дисциплин как вся биология и экспериментальная медицина; невозможно также найти такого директора института, который мог бы объединить в своем лице достаточно авторитетное руководство по всем разделам экспериментальной медицины и, кроме того, был бы хорошо осведомленным научным работником по всем биологическим дисциплинам.

Кроме того, Академия Наук находит целесообразным учредить Музей истории медицины в качестве отдельной структурной единицы Академии Наук, с 2 отделлениями: 1-ое отделение надо организовать на базе существующего уже Музея истории медицины, оборудованного действительным членом Академии Наук Проф. Д-ром П. Страдынем его собственными средствами; экспонаты этого музея размещены в 25 комнатах. 2-е отделение надо организовать на базе наследства покойного Проф. Д-ра П. Сникера. Таково было и желание покойного Проф. Д-ра П. Сникера, чтобы после его смерти был учрежден музей его имени. 114 с./115 c.

Ввиду изложенного просим постановления Совета Министров Латвийской ССР о соответствующих изменениях в уставе и структуре Академии Наук Латвийской ССР.

Президент Академии Наук

Латвийской ССР

Проф. Д-р

/П. Леиньш/

Академик-секретарь

Проф. Д-р

/Я. Пейве/ 


\section{Pielikums № 4}

LZA Arhivs, 1. f., 1. apr., 10. 1., 116. lpp.

Совет Министров Латвийской ССР

Постановление №...

г. Рига, ".." августа 1946 г.

Об изменениях в уставе и структуре Академии Наук Латвийской ССР.

Совет Министров Латвийской ССР постан овля я т:

1. Обязать Академию Наук Латвийской ССР /т. Леиньш/ в 1947 году:

a/ Отделить от Института Биологии и экспериментальной медицины Академии Наук Латвийской ССР Сектор биологии и на базе последнего учредить новый научно-исследовательский институт Биологии Академии Наук Латвийской ССР в качестве отдельной структурной единицы;

6/ Теперешнему Института Биологии и экспериментальной медицины Академии Наук Латвийской ССР дать новое название "Института Экспериментальной медицины Академии Наук Латвийской ССР";

в/ Учредить Музей истории медицины Академии Наук Латвийской ССР в качестве отдельной структурной единицы, с двумя отделениями.

2. В связи вышеизложенным внести в структуру Академии Наук Латвийской ССР /приложение № 1 к уставу Академии Наук Латвийской ССР/ соответствующие изменения и дополнения.

Председатель Совета Министров

Латвийской ССР

/В. Лацис/

Управляющий делами Совета

Министров Латвийской ССС

/Я. Клявиньш/

\section{Pielikums № 5}

LZA Arhīvs, 1. f., 1. apr., 410. 1., 125.-130. lpp.

Протокол № 6/207

заседания Президиума

АКАДЕМИИ НАУК ЛАТВИЙСКОЙ ССР

г. Рига, 5 февраля 1952 г.

/начало заседания в 18 час. 05 мин./ 
Присутствуют: президент АН Я. В. Пейве, вице-президент АН А. М. Кирхенштейн, академик-секретарь АН П. И. Валескалнс; академики-секретари отделений АН: Биологических и сельскохозяйственных наук - А. А. Шмидт, Общественных наук - К. Я. Страздыньш, Технических наук - К. К. Плауде; члены Президиума АН Я. М. Берзиньш, А. И. Калниньш; действительные члены АН А. М. Озолс, Р. А. Пельше, П. И. Страдыньш, Я. Я. Зутис; члены корресподненты АН Я. Я. Бергман, К. М. Граудиньш; секретарь парторганизации АН Э. П. Озолиньш, управляющий делами АН А. К. Сея, начальник отдела кадров Э. П. Керре, ученый секретарь Президиума АН А. Т. Емельянов. Приглашены директора учреждений АН: ...

Председательствует президент АН проф. д-р Я. В. Пейве.

Протоколирует начальник Протокольного отдела АН Я. Я. Магоне.

$=125$. lpp.

Повестка дня:

$\ldots=125$. lpp.

$=126$ c. 3 . О состоянии организации Музея по истории медицины.

Докл. академик-секретарь Отделения биологических

и с $/ \mathrm{x}$ наук А. А. Шмидт

$=126$. lpp.

[..]

По повестке дня Президиум АН постановляет:

Второй пункт, как не вполне подготовленный к обсуждению с повестли дня снять. $=126 \mathrm{c}$.

$=129$ с. 3. По третьему пункту повестки дня заслушивается сообщение академика-секретаря Отделения биологических и с/x наук А. А. Шмидта о состоянии организации Музея по истории медицины.

Обсудив это сообщение и заслушав по данному вопросу предложения действительного члена АН Латв. ССР проф. д-ра П. И. Страдыня, Президиум АН постановляет:

1. Академия наук Латвийской ССР из-за отсутствия свободного помешения для организации Музея по истории медицины не имеет возможности использовать и принять предлагаемые действительным членом АН Латв. ССР профессором д-ром П. И. Страдыньш для этой цели коллекции эксонатов, принадлежащих ему лично.

2. Академия наук считает целесообразным и просит проф. д-ра П. И. Страдыня передать свои ценные коллекции экспонатов Министерству здравоохранения Латвийской ССР для организации при последнем музея по истории здравоохранения.

3. Выразить благодарность действительному члену АН Латв. ССР профессору д-ру П. И. Страдыню за передаваемые Академии наук Латвийской ССР экспонаты по биологии и онкологии. 


\section{J. Stradinš̌, D. Cēbere}

Поручить директору Института Экспериментальной медицины, действ. члену АН А. А. Шмидту принять эти экспонаты по акту от действительного члена АН проф. д-ра П. И. Страдыня и предусмотреть в бюджете Института Экспериментальной медицины необходимые средства для сохранения коллекции по онкологии, а также предусмотреть штатную единицу лаборанта.

4. Для хранения указанных экспонатов поручить управляющему делами АН А. К. Сея выделить соответствующие помещения площадью 70-100м² из общих фондов Академии.

$=129.1 \mathrm{pp}$.

Заседание закрывается в 20 час. 30 мин.

Президент АН ЛССР проф. д-р. Я. Пейве

Академик секретарь АН проф. П. Валескалнс

Протоколировал начальник протокольного отдела АН Я. Магоне

$$
\text { Подписи = оригинал }
$$

\section{Pielikums № 6}

LZA Arhīvs, 1. f., 1. apr., 410. 1., 147-150 c.

Приложение к протоколу Президиума АН Латв. ССР № 6/207 5-го февраля 1952 года.

2. О состоянии организации Музея по истории медицины.

Докл. академик-секретарь Отделения биологических и c/x наук А. А. Шмидт.

Этот вопрос необходимо оформить постановлением. Когда встал вопрос о том, что будет дальше с коллекционным материалом, то столкнулись с проблемой о помещении, которое находится в таком состоянии, что требуется получение больших сумм порядка до 100 т. руб., чтобы дом привести в соответствующее состояние, и поскольку дом принадлежит Академии, то Академия не в состоянии произвести капитальный ремонт, с тем, чтобы окончательно решить вопрос. С вицепрезидентом тов. Деглавом мы ознакомились с материалом и на самом деле так оставить ценный материал нельзя. Пока коллекция занимает помещение около 1000 кв. м., но чтобы ее разместить, потребуется до 2000 кв. м. Академия не распологает таким помещением и когда мы поговорили с секретарем-академиком/Валескалном - aвm./ мы пришли к такому выводу, что академия наук не может использовать ее, так как нужно и не в состоянии создать Музей истории медицины и поэтому после обсуждения вопроса на Бюро отделения решили поставить вопрос перед Академией наук материал, который приобретен на средства Академии и принять дар профессора, который относится к биологии и физиологии. 
Остальной материал передать Министерству здравоохранения в целях организации музея истории медицины, поскольку Академия эксплуатировать Музей истории медицины не в состоянии.

Таким образом передав основной материал Министерству здравоохранения, мы решили оставить небольшую часть, на которую мы можем выделить небольшую часть помещения из общего фонда. Я знаю, что профессор К. сможет нам помочь, я думаю, что там площадь имеется.

Проект постановления имеется, разрешите комиссию не назначать, а мы сами решим этот вопрос.

Тов. СТРАЗДЫНЫШ:/Страдыньш - aвт./: те экспонаты, которые переданы в основу хотя-бы небольшого музея, для этого необходимо 33 комнаты. Министерство здравоохранения, повидимому, не сможет дать другое помешение, чем имеется там на ближайшие пять лет. А так как эти экспонаты расположены, они не могут остаться в таком состоянии, поэтому часть придется законсервировать, иначе они погибнут в ближайшие 3-5 лет. Там можно подобрать 20-30 портретов, сотни две или три крупных фотографий и около 700-800 книг, относящихся к истории медицины. Это было-бы ядро для такого небольшого музея (147\148 с.) институтов, и вот на фоне этого небольшого ядра будут собраны дальнейшие коллекции, которые могут быть использованы если не в эти годы, то в последующем какой-то музей будет создан, учитывая, что в Эстонской и Литовской ССР имеются весьма крупные коллекции, это была-бы просьба. И по второй половине, - это экспонаты по раку, они занимают 4 комнаты, там ряд препаратов и чтобы сохранить эти препапраты для нужд нашего института, я просил бы обсудить возможность утверждения одной единицы лаборантки, больше пока не нужно, и 2-3 тыс. рублей в год для того, чтобы приобретать стекляную посуду и формалин.

И эту экспозицию по раку, которая явится одной из немногих в Союзе, ни в Москве, ни в Ленинграде такого собрания экспонатов нет, может быть неплохо было-бы сохранить. А если невозможно сохранить одну единицу лаборантки и несколько тыс. руб., - /дальше текст стерт ок. 3 слов.

Тов. ПЕЙВЕ: это вполне возможно, 2 тыс. рублей и одна лаборантка - это не проблема, это даже необходимо, как же без коллекции работать.

Тов. ВАЛЕСКАЛНС: Весьма своевременно и с большим удовольствием мы приняли дар профессора Страдынья, там для нас очень много ценнного, но к сожалению это дело не оформили. Дело натолкнулось на большие трудности, часть которых нам преодолеть удалось, но в отношении помещения вы видите, какие это представляет трудности. Музей находится в начале организации, в помещениях очевидно с давних пор ремонта не производилось. Помещение очень мало приспособлено для этого дела, а этот вопрос с помещением мы здесь в Академии наук решить не можем, если-бы даже были деньги. 


\section{J. Stradinš̌, D. Cēbere}

Единственный выход сейчас, это поблагодарить профессора Страдынья и обсудить решение Президиума, которое бы дало возможность найти другое место, где легче будет устроить музей.

Я говорил с Министром здравоохранения по этому вопросу. Для передачи не нужно решение Совета Министров, мы просто это дело не довели до конца, сейчас этого не нужно, если мы договоримся поделить. С министерством я договорился, оно войдет в свое министерство в Москве с ходотайством, чтобы оформить музей в своем помещении.

Мне тоже кажется, что то, что принадлежит Академии наук/148/149 с./ может быть часть из этих экспонатов было-бы целесообразно оставить тоже за Академией наук в виде такого небольшого ядра в будущем для создания музея, но другого типа научно-онкологического, уже другого типа, это нужно оставить.

У меня предложение такое - никакой комиссии не создавать. Поручить тов. Сея продумать, где и как найти помещение, очень хорошо рядом с биологическим музеем, те помещения были бы вполне пригодны, где эти экспонаты разместить. Средства эти действительно дать можно, для того, чтобы сохранить и расширить коллекцию, может со временем найдутся помещения и мы сможем открыть музей при институте.

Тов. ПЕЙВЕ: есть предложение, за исключением комиссии из трех человек, предложение принять.

Поручить директору Института экспериментальной медицины предусмотреть в бюджете Института необходимые средства для сохранения коллекции по онкологии, а также предусмотреть одну штатную единицу лаборантки.

Тов. ШМИДТ: поручить директору института принять и обеспечить дальнейшее сохранение и расширение этого ценного материала для работы Института.

Тов. ПЕЙВЕ: и выразить благодарность профессору Раудыньш/Страдыньш - авт./.

Ш.: Переходим к следующему вопросу:

Рассмотрение и утверждение плана помощи органам здравоохранения. Стенографировала А. (?) Голубева 


\section{Pauls Stradiņš Museum for History of Medicine, a part of Latvian SSR Academy of Science (1946-1952) (Summary)}

\section{By Jānis Stradinš̌ and Dzintra Cēbere}

This article describes that museums phase of development (1945-1952) during which it was operating as a part of the Latvian SSR Academy of Science, Biology and Experimental medicine institute, led by its first director (1946-1951) professor P. Stradinšs. In 1946 a resolution was prepared by the council of the Latvian SSR, which divided the institute in to two parts - Biology institute (separate) and the Institute for experimental medicine (separate). The last institute bound two separate museums - P. Stradiňš Museum for History of Medicine, and P. Snikers museum (in Mežaparks). This resolution was supported by the Executive Council of the Latvian SSRs Academy of Science (Chairman P. Lejiņš), but was not approved by Council of ministers for several reasons. The museum thus continued to function informally under the Institute for Biology and experimental medicine, as long as the institute was being led by professor P. Stradiňs. His successor in the chair of the institute's director - professor A. Šmits did not approve of the situation and gave the museum to the Ministry of Health.

Jānis Stradin̄̌š, profesors, Dr. habil. chem., Dr. hist. h.c.

Dzintra Cēbere

stradins@lza.lv 